\title{
Anti Human Immunodeficiency Virus-1 (HIV-1) Agents 1. Discovery of Benzyl Phenyl Ethers as New HIV-1 Inhibitors in Vitro
}

\author{
Hui-Ling DAI, ${ }^{a, \#}$ Wu-Qing LiU, ${ }^{b, \#}$ Hui Xu, ${ }^{*, a}$ Liu-Meng YANG, ${ }^{b}$ Min Lv, ${ }^{a}$ and Yong-Tang ZhenG ${ }^{*, b}$ \\ ${ }^{a}$ Laboratory of Pharmaceutical Synthesis, College of Sciences, Northwest A\&F University; Yangling 712100, China: and \\ ${ }^{b}$ Laboratory of Molecular Immunopharmacology, Key Laboratory of Animal Models and Human Diseases Mechanisms, \\ Kunming Institute of Zoology, Chinese Academy of Sciences; Kunming 650223, China.
}

Received July 20, 2008; accepted October 13, 2008; published online October 14, 2008

\begin{abstract}
Ten single benzyl phenyl ethers were synthesized and evaluated as human immunodeficiency virus-1 (HIV-1) inhibitors in vitro for the first time. Among these compounds, especially 4-nitrobenzyl phenyl ether (3h) exhibited the highest anti-HIV-1 activity with $\mathrm{EC}_{50}$ (concentration of drug that reduces syncytia formation by $50 \%$ ) value of $5.96 \mu \mathrm{g} / \mathrm{ml}$ and therapeutic index value of 18.32. The preliminary structure-activity relationships of these benzyl phenyl ethers were also described.
\end{abstract}

Key words benzyl phenyl ether; human immunodeficiency virus; inhibitor

Acquired immune-deficiency syndrome (AIDS) is a recently identified syndrome in which a person's immune system after functioning normally ceases to function adequately. In the past twenty years, the standard of care for the treatment of the human immunodeficiency virus (HIV) infection has evolved from the use of single-drug therapy, to dual-nucleoside analogue therapy to the current standard of care, 3drug therapy with 2 nucleoside analogues in combination with a non-nucleoside reverse transcriptase inhibitor or a protease inhibitor. However, many drugs have only limited or transient clinical benefit due to their major side effects (e.g., toxicity problems) and the rapidly development of virus-drug resistance. ${ }^{1)}$ Based on the AIDS crisis, therefore, the discovery and development of new, selective, efficacy and safe HIV-1 inhibitors still remains a high priority and challenge for medical research. ${ }^{2-5)}$ Benzyl aryl ethers (BAEs) are found many applications as starting materials in organic synthesis and in analytical chemistry, such as the synthesis of diboronic acids, dendrimers and dendritic polymers, and ortho lithiation of BAEs to react with electrophiles. ${ }^{6-8)}$ To the best of our knowledge, the anti-HIV-1 activity of the single benzyl phenyl ethers has not been previously studied. In previous paper, we found that some single $N$-arylindoles demonstrated significant anti-HIV-1 activity in vitro. ${ }^{9)}$ These encouraging results prompted us to study the anti-HIV-1 activ- ity of some other single compounds. Meanwhile, according to our program aimed at the discovery and development of bioactive molecules, ${ }^{9-14)}$ in this paper we want to report the synthesis and anti-HIV-1 activity of some single benzyl phenyl ethers for the first time.

\section{Results and Discussion}

As shown in Chart 1, firstly, ten single benzyl phenyl ethers $\mathbf{3 a}-\mathbf{j}$ (Fig. 1) were prepared successfully by the reaction of the appropriate phenols with benzyl chloride or substituted benzyl methanesulfonates in the presence of $\mathrm{K}_{2} \mathrm{CO}_{3}$, and were characterized by ${ }^{1} \mathrm{H}-\mathrm{NMR}(400 \mathrm{MHz})$, EI-MS and melting point. Then the benzyl phenyl ethers $\mathbf{3 a}-\mathbf{j}$ were tested in vitro for their anti-HIV-1 activity and 3 '-azido-3'deoxythymidine (AZT) was used as a positive control as shown in Table 1.

Among these tested benzyl phenyl ethers, fortunately,

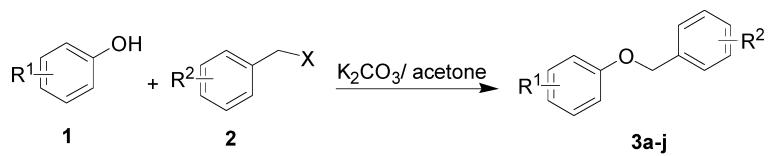

$\mathrm{R}^{1}=\mathrm{H}, \mathrm{Cl}, \mathrm{NO}_{2}, \mathrm{Me}, \mathrm{Bu}(t) ; \mathrm{R}^{2}=\mathrm{H}, \mathrm{NO}_{2}, \mathrm{OMe} ; \mathrm{X}=\mathrm{Cl}$ or OMs

Chart 1. The Synthetic Route of Benzyl Phenyl Ethers $\mathbf{3 a}-\mathbf{j}$

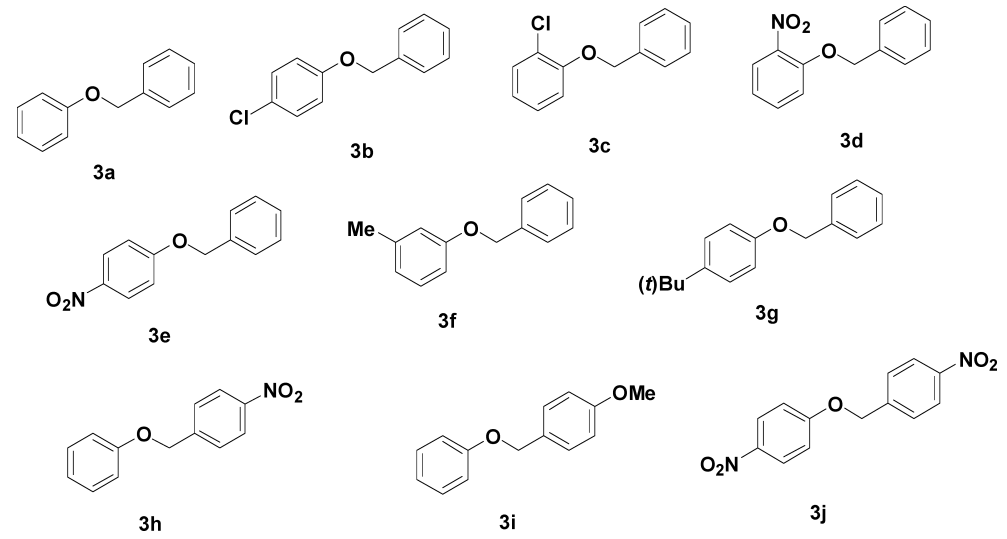

Fig. 1. Structures of Different Benzyl Phenyl Ethers $3 \mathbf{a}-\mathbf{j}$

* To whom correspondence should be addressed. e-mail: orgxuhui@nwsuaf.edu.cn; zhengyt@mail.kiz.ac.cn 
Table 1. Anti-HIV-1 Activity of Benzyl Phenyl Ethers $(\mathbf{3 a}-\mathbf{j})$ in Vitro $^{a}$ )

\begin{tabular}{cccr}
\hline \hline Compounds & $\mathrm{CC}_{50}{ }^{b}(\mu \mathrm{g} / \mathrm{ml})$ & $\left.\mathrm{EC}_{50}{ }^{c}\right)(\mu \mathrm{g} / \mathrm{ml})$ & $\mathrm{TI}^{d)}$ \\
\hline 3a & 197.83 & 57.99 & 3.41 \\
3b & 106.04 & 11.53 & 9.19 \\
$\mathbf{3 c}$ & 108.71 & 29.36 & 3.70 \\
$\mathbf{3 d}$ & 117.14 & 12.53 & 9.34 \\
$\mathbf{3 e}$ & 182.79 & 53.26 & 3.43 \\
$\mathbf{3 f}$ & 134.75 & 44.87 & 3.00 \\
$\mathbf{3 g}$ & 117.64 & 15.48 & 7.59 \\
$\mathbf{3 h}$ & 109.20 & 5.96 & 18.32 \\
$\mathbf{3 i}$ & 151.65 & 18.14 & 8.36 \\
$\mathbf{3 j}$ & 169.36 & 58.20 & 2.91 \\
$\mathrm{AZT}$ & 1307.39 & 0.0024 & 544745.83 \\
\hline
\end{tabular}

a) Values are means of two separate experiments; $b) \mathrm{CC}_{50}(50 \%$ cytotoxic concentration), concentration of drug that causes $50 \%$ reduction in total $\mathrm{C} 8166$ cell number; $c$ ) $\mathrm{EC}_{50}(50 \%$ effective concentration), concentration of drug that reduces syncytia formation by $50 \% ; d$ ) therapeutic index (TI) is a ratio of the $\mathrm{CC}_{50}$ value/EC $\mathrm{E}_{50}$ value; $e$ ) AZT was used as a positive control.

compounds $\mathbf{3 b}, \mathbf{3 d}, \mathbf{3 g}, \mathbf{3 h}$ and $\mathbf{3 i}$ showed the more potent anti-HIV-1 activity with $50 \%$ effective concentration $\left(\mathrm{EC}_{50}\right)$ values of $11.53,12.53,15.48,5.96$ and $18.14 \mu \mathrm{g} / \mathrm{ml}$, and therapeutic index (TI) values of 9.19, 9.34, 7.59, 18.32 and 8.36, respectively. Especially compound $\mathbf{3 h}$ exhibited the most potent and promising anti-HIV-1 activity with $\mathrm{EC}_{50}$ value of $5.96 \mu \mathrm{g} / \mathrm{ml}$ and TI value of 18.32 , which was as potent as $N$-(2-nitrophenyl)indole with $\mathrm{EC}_{50}$ value of 7.88 $\mu \mathrm{g} / \mathrm{ml}$ and TI value of $24.61 .^{9)}$

From the comparative study, it is possible to draw some preliminary structure-activity relationships on these benzyl phenyl ethers. As indicated in Table 1, the $\mathrm{EC}_{50}$ and TI values of 3a, 3b and 3c were 57.99/11.53/29.36 $\mu \mathrm{g} / \mathrm{ml}$, and 3.41/9.19/3.70, respectively. Obviously, introducing chloro group on the para position on the phenyl ring of compound 3a, would lead to give more potent compound than that having ortho-chloro group on the phenyl ring (3b vs. 3c). On the contrary, when nitro group was introduced on the ortho or para position on the phenyl ring of compound $\mathbf{3 a}$, the $\mathrm{EC}_{50}$ and TI values of the corresponding compounds $\mathbf{3 d}$ and $\mathbf{3 e}$ were $12.53 / 53.26 \mu \mathrm{g} / \mathrm{ml}$, and $9.34 / 3.43$, respectively. The $\mathrm{EC}_{50}$ and $\mathrm{TI}$ values of compounds $\mathbf{3 f}$, having meso-methyl group on the phenyl ring, and $\mathbf{3 g}$, having para-tert-butyl group on the phenyl ring, were $44.87 / 15.48 \mu \mathrm{g} / \mathrm{ml}$, and $3.00 / 7.59$, respectively. Consequently, introducing electrondonating group on the para position on the phenyl ring of $\mathbf{3 a}$, would give more potent compound than that having electrondonating group on meso position on the phenyl ring. Meantime, when electron-donating group (tert-butyl group) was introduced on the para position on the phenyl ring of $\mathbf{3 a}$, it will give more potent compound than that having electronwithdrawing group (nitro group) on the para position on the phenyl ring (3g vs. 3e). The $\mathrm{EC}_{50}$ and TI values of $\mathbf{3 a}, \mathbf{3 e}$ and 3h were $57.99 / 53.26 / 5.96 \mu \mathrm{g} / \mathrm{ml}$, and $3.41 / 3.43 / 18.32$, respectively. That is, the TI value of $\mathbf{3 h}$ was more than 5 times of those of $\mathbf{3} \mathbf{a}$ and $\mathbf{3 e}$, and the $\mathrm{EC}_{50}$ of $\mathbf{3 h}$ was almost decreased 9 times compared with $\mathbf{3 a}$ and $\mathbf{3 e}$. Therefore, introducing nitro group on the para position on the benzyl ring of 3a will give more active compound than that having paranitro group on the phenyl ring ( $\mathbf{3 h} v s$. $\mathbf{3 e}$ ).

Once the nitro group (electron-withdrawing group) on the para position on the benzyl ring of compound $\mathbf{3 h}$ was substituted by the methoxy group (electron-donating group) to give compound 3i, however, the anti-HIV-1 activity of which was decreased more than twice compared with $\mathbf{3 h}$. For example, the $\mathrm{EC}_{50}$ and $\mathrm{TI}$ values of $\mathbf{3 h}$ and $\mathbf{3 i}$ were $5.96 / 18.14 \mu \mathrm{g} / \mathrm{ml}$, and 18.32/8.36, respectively.

Interestingly, when the nitro group was introduced on the para position on the phenyl ring of $\mathbf{3} \mathbf{h}$ to give $\mathbf{3} \mathbf{j}$, the antiHIV-1 activity of which was sharply decreased compared with $\mathbf{3 h}$. For example, The $\mathrm{EC}_{50}$ and TI values of $\mathbf{3 h}$ and $\mathbf{3 j}$ were $5.96 / 58.20 \mu \mathrm{g} / \mathrm{ml}$, and $18.32 / 2.91$, respectively. The anti-HIV-1 activity of $\mathbf{3 h}$ was nearly 10 times of that of $\mathbf{3 j}$. Based upon the above investigation, the nitro group on the para position on the benzyl ring certainly is an important functional group for $\mathbf{3 h}$ being good HIV-1 inhibitory activity. In addition, the mechanisms of the anti-HIV-1 function of these compounds, of course, need to be studied further.

\section{Conclusion}

In summary, ten single benzyl phenyl ethers were synthesized and evaluated in vitro as HIV-1 inhibitors. Compounds 3b, 3d, 3g, 3h and 3i demonstrated significant anti-HIV-1 activity as displayed in Table $\mathbf{1}$; especially compound $\mathbf{3 h}$ showed the most promising and best activity against HIV-1, which will pave the way for further optimal structural modifications of the benzyl phenyl ethers to discover the more potent compounds possessing anti-HIV-1 activity.

\section{Experimental}

All the solvents were of analytical grade and the reagents were used as purchased. Thin-layer chromatography (TLC) and preparative thin-layer chromatography (PTLC) were performed with silica gel plates using silica gel $60 \mathrm{GF}_{254}$ (Qingdao Haiyang Chemical Co., Ltd.). Melting points were determined on a digital melting-point apparatus and were uncorrected. ${ }^{1} \mathrm{H}$ NMR spectra were recorded on a Bruker Avance DMX $400 \mathrm{MHz}$ instrument using TMS as internal standard and $\mathrm{CDCl}_{3}$ as solvent. EI-MS was carried out with Thermo DSQ GC/MS instrument.

General Procedure for the Synthesis of Benzyl Phenyl Ethers 3a-j The mixture of the appropriate phenols $(\mathbf{1}, 1.1 \mathrm{mmol})$, benzyl chloride or substituted benzyl methanesulfonates $(2,1.0 \mathrm{mmol})$, and anhydrous $\mathrm{K}_{2} \mathrm{CO}_{3}$ $(3.6 \mathrm{mmol})$ in acetone $(10 \mathrm{ml})$ was stirred under reflux in an air atmosphere (for benzyl chloride, $0.3 \mathrm{mmol} \mathrm{KI}$ was used as a catalyst). When the reaction was complete checked by TLC, the mixture was cooled to r.t., filtered, and purified by preparative TLC to give the pure benzyl phenyl ethers $(\mathbf{3 a}-\mathbf{j})$ which were all known compounds and characterized by ${ }^{1} \mathrm{H}-\mathrm{NMR}$ (400 MHz), EI-MS and mp.

3a: Yield: $87 \%$, white solid, mp $38-39^{\circ} \mathrm{C}$ (lit., ${ }^{15)} 37-38^{\circ} \mathrm{C}$ ); ${ }^{1} \mathrm{H}-\mathrm{NMR}$ $\left(400 \mathrm{MHz}, \mathrm{CDCl}_{3}\right) \delta: 5.06(2 \mathrm{H}, \mathrm{s}), 6.93(3 \mathrm{H}, \mathrm{m}), 7.24(3 \mathrm{H}, \mathrm{m}), 7.35(4 \mathrm{H}$ $\mathrm{m})$; EI-MS $m / z: 184\left(\mathrm{M}^{+}, 18\right), 91\left(\left[\mathrm{C}_{6} \mathrm{H}_{5} \mathrm{CH}_{2}\right]^{+}, 100\right)$.

3b: Yield: $96 \%$, light yellow solid, mp $71-72{ }^{\circ} \mathrm{C}$ (lit., ${ }^{15)} 70-71{ }^{\circ} \mathrm{C}$ ); ${ }^{1} \mathrm{H}-$ NMR $\left(400 \mathrm{MHz}, \mathrm{CDCl}_{3}\right) \delta: 5.03(2 \mathrm{H}, \mathrm{s}), 6.87(2 \mathrm{H}, \mathrm{m}), 7.20(2 \mathrm{H}, \mathrm{m}), 7.30$ $(1 \mathrm{H}, \mathrm{m}), 7.35(4 \mathrm{H}, \mathrm{m})$; EI-MS $m / z: 220\left(\mathrm{M}^{+}, 5\right), 218\left(\mathrm{M}^{+}, 16\right), 91$ $\left(\left[\mathrm{C}_{6} \mathrm{H}_{5} \mathrm{CH}_{2}\right]^{+}, 100\right)$

3c: Yield: $84 \%$, light yellow liquid ${ }^{16)}$; ${ }^{1} \mathrm{H}-\mathrm{NMR}\left(400 \mathrm{MHz}, \mathrm{CDCl}_{3}\right) \delta$ : $5.14(2 \mathrm{H}, \mathrm{s}), 6.87(1 \mathrm{H}, \mathrm{m}), 6.95(1 \mathrm{H}, \mathrm{d}, J=8 \mathrm{~Hz}), 7.14(1 \mathrm{H}, \mathrm{m}), 7.29(1 \mathrm{H}$ m), $7.35(3 \mathrm{H}, \mathrm{m}), 7.45(2 \mathrm{H}, \mathrm{d}, J=7.6 \mathrm{~Hz})$; EI-MS $m / z: 220\left(\mathrm{M}^{+}, 3\right), 218$ $\left(\mathrm{M}^{+}, 10\right), 91\left(\left[\mathrm{C}_{6} \mathrm{H}_{5} \mathrm{CH}_{2}\right]^{+}, 100\right)$.

3d: Yield: $89 \%$, light yellow liquid ${ }^{17)}$; ${ }^{1} \mathrm{H}-\mathrm{NMR}\left(400 \mathrm{MHz}, \mathrm{CDCl}_{3}\right) \delta$ : $5.22(2 \mathrm{H}, \mathrm{s}), 6.99(1 \mathrm{H}, \mathrm{m}), 7.10(1 \mathrm{H}, \mathrm{dd}, J=8.4,0.8 \mathrm{~Hz}), 7.29(1 \mathrm{H}, \mathrm{m}), 7.35$ $(2 \mathrm{H}, \mathrm{m}), 7.43(2 \mathrm{H}, \mathrm{m}), 7.47(1 \mathrm{H}, \mathrm{m}), 7.83(1 \mathrm{H}, \mathrm{dd}, J=8.0,1.6 \mathrm{~Hz}) ;$ EI-MS $m / z: 229\left(\mathrm{M}^{+}, 1\right), 90.9\left(\left[\mathrm{C}_{6} \mathrm{H}_{5} \mathrm{CH}_{2}\right]^{+}, 100\right)$

3e: Yield: $91 \%$, white solid, mp $105-107^{\circ} \mathrm{C}$ (lit., ${ }^{18)} 105-107^{\circ} \mathrm{C}$ ); ${ }^{1} \mathrm{H}-$ NMR $\left(400 \mathrm{MHz}, \mathrm{CDCl}_{3}\right) \delta: 5.15(2 \mathrm{H}, \mathrm{s}), 7.02(2 \mathrm{H}, \mathrm{dd}, J=7.2,2.0 \mathrm{~Hz}), 7.36$ $(1 \mathrm{H}, \mathrm{m}), 7.39(4 \mathrm{H}, \mathrm{m}), 8.19$ (2H, dd, $J=7.2,2.0 \mathrm{~Hz})$; EI-MS m/z: $229\left(\mathrm{M}^{+}\right.$ 7), $90.9\left(\left[\mathrm{C}_{6} \mathrm{H}_{5} \mathrm{CH}_{2}\right]^{+}, 100\right)$.

3f: Yield: $93 \%$, white solid, mp $48-49^{\circ} \mathrm{C}$ (lit., ${ }^{19)} 45-46{ }^{\circ} \mathrm{C}$ ); ${ }^{1} \mathrm{H}-\mathrm{NMR}$ $\left(400 \mathrm{MHz}, \mathrm{CDCl}_{3}\right) \delta: 3.32(3 \mathrm{H}, \mathrm{s}), 5.04(2 \mathrm{H}, \mathrm{s}), 6.76(3 \mathrm{H}, \mathrm{m}), 7.14(1 \mathrm{H}, \mathrm{m})$, $7.31(3 \mathrm{H}, \mathrm{m}), 7.42(2 \mathrm{H}, \mathrm{m})$; EI-MS $m / z: 198\left(\mathrm{M}^{+}, 28\right), 90.9\left(\left[\mathrm{C}_{6} \mathrm{H}_{5} \mathrm{CH}_{2}\right]^{+}\right.$, $100)$.

4g Yield: $95 \%$, white solid, mp $64-65^{\circ} \mathrm{C}$ (lit., ${ }^{20)} 61-62{ }^{\circ} \mathrm{C}$ ); ${ }^{1} \mathrm{H}-\mathrm{NMR}$ $\left(400 \mathrm{MHz}, \mathrm{CDCl}_{3}\right) \delta: 1.29(9 \mathrm{H}, \mathrm{s}), 5.03(2 \mathrm{H}, \mathrm{s}), 6.89(1 \mathrm{H}, \mathrm{m}), 7.28(3 \mathrm{H}, \mathrm{m})$, 
$7.34(2 \mathrm{H}, \mathrm{m}), 7.41(3 \mathrm{H}, \mathrm{m})$; EI-MS m/z: $240\left(\mathrm{M}^{+}, 29\right), 90.9\left(\left[\mathrm{C}_{6} \mathrm{H}_{5} \mathrm{CH}_{2}\right]^{+}\right.$, $100)$.

3h: Yield: 50\%, light yellow solid, mp $85-87^{\circ} \mathrm{C}$ (lit., ${ }^{18)} 89-91{ }^{\circ} \mathrm{C}$ ); ${ }^{1} \mathrm{H}$ NMR (400 MHz, $\left.\mathrm{CDCl}_{3}\right) \delta: 5.17(2 \mathrm{H}, \mathrm{s}), 6.94(3 \mathrm{H}, \mathrm{m}), 7.30(2 \mathrm{H}, \mathrm{m}), 7.60$ $(2 \mathrm{H}, \mathrm{d}, J=8.8 \mathrm{~Hz}), 8.23(2 \mathrm{H}, \mathrm{d}, J=8.8 \mathrm{~Hz})$; EI-MS $m / z: 229\left(\mathrm{M}^{+}, 70\right), 136$ $\left(\left[(p) \mathrm{NO}_{2}-\mathrm{C}_{6} \mathrm{H}_{5} \mathrm{CH}_{2}\right]^{+}, 100\right)$.

3i: Yield: $26 \%$, white solid, mp $91-93{ }^{\circ} \mathrm{C}$ (lit. ${ }^{21)} 93-93.5^{\circ} \mathrm{C}$ ); ${ }^{1} \mathrm{H}-\mathrm{NMR}$ $\left(400 \mathrm{MHz}, \mathrm{CDCl}_{3}\right) \delta: 3.80(3 \mathrm{H}, \mathrm{s}), 4.98(2 \mathrm{H}, \mathrm{s}), 6.89(5 \mathrm{H}, \mathrm{m}), 7.25(2 \mathrm{H}, \mathrm{m})$, $7.35(2 \mathrm{H}, \mathrm{d}, J=8.8 \mathrm{~Hz})$; EI-MS $m / z: 214\left(\mathrm{M}^{+}, 9\right), 121\left(\left[(p) \mathrm{CH}_{3} \mathrm{O}-\right.\right.$ $\left.\left.\mathrm{C}_{6} \mathrm{H}_{5} \mathrm{CH}_{2}\right]^{+}, 100\right)$.

3j: Yield: $72 \%$, light yellow solid, mp $190-192{ }^{\circ} \mathrm{C}$ (lit., ${ }^{22)} 187.4{ }^{\circ} \mathrm{C}$ ); ${ }^{1} \mathrm{H}$ NMR $\left(400 \mathrm{MHz}, \mathrm{CDCl}_{3}\right) \delta: 5.27(2 \mathrm{H}, \mathrm{s}), 7.02(2 \mathrm{H}, \mathrm{m}), 7.61(2 \mathrm{H}, \mathrm{d}$, $J=8.4 \mathrm{~Hz}), 8.21(2 \mathrm{H}, \mathrm{m}), 8.26(2 \mathrm{H}, \mathrm{d}, J=8.8 \mathrm{~Hz})$; EI-MS $m / z: 274\left(\mathrm{M}^{+}, 3\right)$.

Anti-HIV-1 Activity Assay. Cells and Virus Cell line (C8166) and the laboratory-derived virus $\left(\mathrm{HIV}-1_{\text {IIIB }}\right)$ were obtained from MRC, AIDS Reagent Project, U.K. C8166 was maintained in RPMI-1640 supplemented with $10 \%$ heat-inactivated newborn calf serum (Gibco). The cells used in all experiments were in log-phase growth. The $50 \%$ HIV- $1_{\text {IIIB }}$ tissue culture infectious dose $\left(\right.$ TCID $\left._{50}\right)$ in C8166 cells was determined and calculated by the Reed and Muench method. Virus stocks were stored in small aliquots at $-70{ }^{\circ} \mathrm{C}^{23)}$

MTT-Based Cytotoxicity Assay Cellular toxicity of compounds $\mathbf{3 a}-\mathbf{j}$ on C8166 cells was assessed by 3-(4,5-dimethylthiazol-2-yl)-2,5-diphenyltetrazolium bromide (MTT) method as described previously. ${ }^{24)}$ Briefly, cells were seeded on 96-well microtiter plate in the absence or presence of various concentrations of compounds in triplicate and incubated at $37^{\circ} \mathrm{C}$ in a humid atmosphere of $5 \% \mathrm{CO}_{2}$ for $3 \mathrm{~d}$. The supernatants were discarded and MTT reagent $(5 \mathrm{mg} / \mathrm{ml}$ in PBS) was added to each wells, then incubated for $4 \mathrm{~h}, 100 \mu \mathrm{l}$ of $50 \% \mathrm{~N}, N$-dimethylformamide (DMF)-20\% SDS was added. After the formazan was dissolved completely, the plates were read on a BioTek Elx 800 ELISA reader at 595/630 $\mathrm{nm}$. The cytotoxic concentration that caused the reduction of viable $\mathrm{C} 8166$ cells by $50 \%\left(\mathrm{CC}_{50}\right)$ was determined from dose-response curve.

Syncytia Assay In the presence of $100 \mu$ l various concentrations of compounds, C8166 cells $\left(4 \times 10^{5} / \mathrm{ml}\right)$ were infected with virus HIV- $1_{\text {IIIB }}$ at a multiplicity of infection (M.O.I.) of 0.06 . The final volume per well was $200 \mu \mathrm{l}$. Control assays were performed without the testing compounds in HIV- $1_{\text {IIIB }}$ infected and uninfected cultures. After $3 \mathrm{~d}$ of culture, the cytopathic effect (CPE) was measured by counting the number of syncytia. Percentage inhibition of syncytia formation was calculated and $50 \%$ effective concentration $\left(\mathrm{EC}_{50}\right)$ was calculated. AZT (Sigma) was used as a positive control. Therapeutic index $(\mathrm{TI})=\mathrm{CC}_{50} / \mathrm{EC}_{50}{ }^{25}{ }^{2}$

Acknowledgments This work has been supported by the program for New Century Excellent University Talents, State Education Ministry of China (NCET-06-0868), the Key Project of Chinese Ministry of Education (No. 107105), and the Research Fund for the Doctoral Program of Higher Education of China (No. 20070712025). We also would like to acknowledge
Key Scientific and Technological projects of Yunnan province (2004NG12), National 973 project of China (2006CB504200), and the Knowledge Innovation Program of CAS (KSCX1-YW-R-24).

\section{References}

1) Johston M. I., Hoth D. F., Science, 260, 1286-1293 (1993).

2) Chiang C. C., Mouscadet J. F., Tsai H. J., Liu C. T., Hsu L. Y., Chem. Pharm. Bull., 55, 1740-1743 (2007).

3) Su C. X., Mouscadet J. F., Chiang C. C., Tsai H. J., Hsu L. Y., Chem. Pharm. Bull., 54, 682-686(2006).

4) Ji L., Chen F. E., Feng X. Q., de Clercq E., Balzarini J., Pannecouque C., Chem. Pharm. Bull., 54, 1248-1253 (2006).

5) Maruyama T., Kozai S., Demizu Y., Witvrouw M., Pannecouque C., Balzarini J., Snoecks R., Andrei G., de Clercq E., Chem. Pharm. Bull., 54, 325-333 (2006).

6) Klis T., Serwatowski J., Tetrahedron Lett., 48, 1169-1173 (2007).

7) Chodakowski J., Klis T., Serwatowski J., Tetrahedron Lett., 46, 1963 1965 (2005).

8) Maiti A. K., Martinez R., Mestres R., Tortajada A., Villar F., Tetrahedron, 57, 3397-3401 (2001).

9) Xu H., Liu W. Q., Fan L. L., Chen Y., Yang L. M., Lv L., Zheng Y. T., Chem. Pharm. Bull., 56, 720-722 (2008).

10) Xu H., Desrivot J., Bories C., Loiseau P. M., Franck X., Hocquemiller R., Figadere B., Bioorg. Med. Chem. Lett., 16, 815-820 (2006).

11) Xu H., Jian K. Z., Guan Q., Ye F., Lv M., Chem. Pharm. Bull., 55, 1755-1757 (2007)

12) Xu H., Zhang X., Tian X., Lu M., Wang Y. G., Chem. Pharm. Bull., 50, 399-402 (2002).

13) Xu H., Fan L. L., Chem. Pharm. Bull., 56, 1496-1498 (2008)

14) Xu H., Zhang L., Su, B. F., Zhang X., Tian X., Heterocycles, published online, 28th June, 2008

15) Lourenco N. M. T., Afonso C. A. M., Tetrahedron, 59, 789-794 (2003).

16) Huston R. C., J. Am. Chem. Soc., 55, 4639-4643 (1933)

17) Majumder P. L., J. Indian Chem. Soc., 66, 673-680 (1989).

18) Maslak P., Guthrie R. D., J. Am. Chem. Soc., 108, 2628-2636 (1986).

19) Huston R. C., Houk A. L., J. Am. Chem. Soc., 54, 1506-1510 (1932)

20) Wen X. M., J. Chem. Res., 10, 663-664 (2005).

21) Forrester J., Jones R. V. H., Newton L., Preston P. N., Tetrahedron, 57, $2871-2884$ (2001).

22) Lyman J. A., Reid E. E., J. Am. Chem. Soc., 42, 615-619 (1920).

23) Zhang G. H., Wang Q., Chen J. J., Zhang X. M., Tam S. C., Zheng Y. T., Biochem. Biophys. Res. Commun., 334, 812-816 (2005).

24) Zheng Y. T., Zhang W. F., Ben K. L., Wang J. H., Immunopharmacol. Immunotoxicol., 17, 69-79 (1995).

25) Wang Q., Ding Z. H., Liu J. K., Zheng Y. T., Antiviral Res., 64, 189194 (2004). 